\title{
The Peculiar Indifference to Breastfeeding Disparities in the African American Community
}

\author{
Sahira Long
}

$\mathbf{I}$ N October 2000, U.S. Surgeon General Dr. David Satcher released the first comprehensive blueprint to increase breastfeeding rates. Dr. Satcher stated that "Low breastfeeding rates documented in the Blueprint for Action is a serious public health challenge, particularly in certain minority communities... With scientific evidence indicating that breastfeeding can play an important role in an infant's health, the time has come for us to work together to promote optimal breastfeeding practices." African Americans were included in the communities to which he referred. In a seminal study conducted over a century ago, African American sociologist W. E. B. Du Bois stated the following regarding the condition of 40,000 or more people of "Negro blood" living in Philadelphia in 1896: "The most difficult social problem in the matter of Negro health is the peculiar attitude of the nation toward the well-being of the race. There have... been few other cases in the history of civilized peoples where human suffering has been viewed with such peculiar indifference.' W. E. B. Du Bois (1967 p.163). ${ }^{1}$ The words of this study, unfortunately, still ring true today as disparities in health still plague the African American community and other disenfranchised people. What W. E. B. Du Bois and other sociologist knew all along that science is confirming is that race is a social construct with no biological or genetic basis. To me, this means that any disparities we have identified are, at least in part, socially mediated. Following that logic, the solutions for such disparities, including those in breastfeeding, can also be socially mediated.

In June 2019, after the U.S. Breastfeeding Committee African American/Black Identity Caucus meeting, a group of participants discussed the possibility of writing an article together on the topic of Black breastfeeding disparities and solutions to address them. The concept, we thought, would be similar to a "white paper," however, it would be Black authors writing so we termed it a "Black paper." I agreed to speak with Dr. Eidelman to see whether this Black paper was, in fact, something he thought would be printable in Breastfeeding Medicine when we were together at the Academy of Breastfeeding Medicine meeting in the United Kingdom. This special issue was born out of that conversation. More than 30 abstracts submitted for inclusion consideration were carefully reviewed and scored by a committee I led which included three phenomenal African American women: Drs. Kimarie Bugg, Camille Clare, and Michal Young. It is my hope that this effort to shed light on some of ways in which the "peculiar indifference" toward disparities in breastfeeding rates among African Americans is being addressed will leave you just as inspired as I was while editing this landmark issue.

\section{Reference}

1. Du Bois WEB. The Philadelphia Negro: A Social Study. New York: Schocken Books, 1967.

Address correspondence to: Sahira Long, MD, IBCLC, FAAP, FABM Children's National Health System 2101 Martin Luther King, Jr. Ave., SE 5th Floor Washington, DC 20020

USA

E-mail: slong@childrensnational.org

Children's National Health System, Washington, District of Columbia, USA. 